\title{
Evaluation of methane emissions by spring calving Holstein Friesian dairy cows offered a grass- only diet or a total mixed ration
}

\author{
B F O'Neill ${ }^{1,2}$, M Deighton ${ }^{1}$, B O'Loughlin ${ }^{1}$, F J Mulligan ${ }^{2}$, M O'Donovan ${ }^{1}$, E Lewis $^{1}$ \\ ${ }^{1}$ Teagasc,Moorepark Dairy Production Research Centre,, Fermoy, Co. Cork, Ireland \\ ${ }^{2}$ University College Dublin. School of Agriculture, Food Science and Veterinary Medicine, Belfield, Dublin 4, Ireland \\ Email:brendan.oneill@teagasc.ie
}

Introduction Under the Kyoto Protocol (1997) Ireland agreed to limit its greenhouse gas (GHG) emissions to $13 \%$ above 1990 levels during the first commitment period 2008-2012. Ireland is legally bound to meet this GHG emissions reduction target. Agriculture in Ireland is the largest contributor to total GHG emissions $(26.6 \%)$. Eighty per cent of the methane emissions from agriculture in 2006 came from enteric fermentation (McGettigan et al, 2008). Manipulating the diet of dairy cows is considered a strategy to mitigate methane production. The objective of the current experiment was to investigate the methane emissions and milk production response when spring calving Holstein Friesian dairy cows were offered a grass-only or total mixed ration (TMR) diet.

Materials and methods Forty eight spring calving Holstein Friesian dairy cows (18 primiparous and 30 multiparous) were randomly assigned to one of two nutritional treatments for 10 weeks: (1) Grass-only (grazing unsupplemented perennial ryegrass pasture) (2) TMR (offered ad libitum indoors). Animals were blocked according to parity, bodyweight (BW), body condition score, days in milk and milk yield. The TMR offered per cow per day was composed of maize silage $(7.5 \mathrm{~kg}$ $\mathrm{DM})$, concentrate blend (8.6 kg DM), grass silage (3.5 kg DM), molasses (0.7 kg DM) and straw (0.5 kg DM). The pregrazing herbage mass was $1492 \mathrm{~kg} \mathrm{DM} / \mathrm{ha}(\mathrm{S} . \mathrm{D}=332 \mathrm{~kg}$ ). Pre- and post-grazing sward heights were measured (platemeter) before and after each grazing. The average pre- and post-grazing sward heights for the trial period were $9.4 \mathrm{~cm}(\mathrm{~S} . \mathrm{D}=1.26$ $\mathrm{cm})$ and $4.1 \mathrm{~cm}(\mathrm{~S} . \mathrm{D}=0.51 \mathrm{~cm})$ respectively. Milk yield was recorded daily while milk composition was determined weekly from one evening and one morning milk sample taken on consecutive days. Bodyweight was also recorded weekly. Daily methane emissions were measured during weeks 4 and 10 of the trial for a 5-day period using the sulphur hexafluoride $\left(\mathrm{SF}_{6}\right)$ tracer gas technique. Herbage DM intakes for the grass-only cows were estimated using the n-alkane technique as modified by Dillon and Stakelum (1989). DM intakes for the TMR cows were recorded using the Griffith Elder ${ }^{\circledR}$ feeding system The data were analysed by analysis of variance with a model which included terms for treatment, lactation number and days in milk and using covariate analysis for milk yield, milk composition and bodyweight (SAS Institute, 2003).

Results TMR cows had significantly $(\mathrm{P}<0.01)$ higher milk yield, milk solids yield, BW, total dry matter intake (TDMI) and $\mathrm{CH}_{4}$ emissions (g/day) than grass-only cows in both measurement periods. However, grass-only cows had higher $(\mathrm{P}<0.05)$ milk protein content and lower $(\mathrm{P}<0.05) \mathrm{CH}_{4}$ emissions per unit milk solids and per unit $\mathrm{BW}$ in both measurement periods. They also had lower $\mathrm{CH}_{4}$ emissions per unit intake in the second measurement period $(\mathrm{P}<0.001)$.

Table 1 Milk production and methane emissions from spring calving dairy cows offered a grass-only or TMR diet

\begin{tabular}{lcccccccc} 
& \multicolumn{3}{c}{ Week 4 } & Measurement Period 1 & \multicolumn{4}{c}{ Week 10- Measurement Period 2 } \\
& Grass & TMR & s.e.d & Sig. & Grass & TMR & s.e.d & Sig. \\
\hline Milk yield (kg/day) & 20.8 & 28.4 & 1.00 & 0.001 & 18.1 & 26.4 & 0.66 & 0.001 \\
Milk solids (kg/day) & 1.58 & 2.07 & 0.073 & 0.001 & 1.36 & 1.91 & 0.056 & 0.001 \\
Milk fat content (g/kg) & 43.2 & 42.5 & 1.38 & 0.63 & 40.7 & 40.1 & 0.130 & 0.68 \\
Milk protein content (g/kg) & 32.3 & 30.8 & 0.41 & 0.001 & 34.0 & 32.6 & 0.55 & 0.02 \\
Bodyweight (kg) & 475 & 534 & 5.0 & 0.001 & 482 & 547 & 6.7 & 0.001 \\
TDMI (kg DM/day) & 13.3 & 18.8 & 0.72 & 0.01 & 15.7 & 20.4 & 0.67 & 0.001 \\
\hline $\mathrm{CH}_{4}$ emissions (g/day) & 243 & 384 & 10.9 & 0.001 & 258 & 410 & 9.2 & 0.001 \\
$\mathrm{CH}_{4}$ emissions (g/kg DMI) & 19.1 & 20.4 & 0.95 & 0.18 & 17.1 & 20.1 & 0.82 & 0.001 \\
$\mathrm{CH}_{4}$ emissions (g/kg milk solids) & 157 & 185 & 6.7 & 0.001 & 196 & 213 & 7.7 & 0.02 \\
$\mathrm{CH}_{4}$ emissions (g/kg BW) & 0.51 & 0.72 & 0.019 & 0.001 & 0.54 & 0.75 & 0.022 & 0.001 \\
\hline \hline
\end{tabular}

Conclusions This study indicates that grazing dairy cows emit less methane per cow and per kg of milk solids produced in comparison to TMR-fed cows. Hence, feeding grass-only diets is a strategy for decreasing enteric methane emissions from dairy production systems.

Acknowledgements Financial support from the Research Stimulus Fund of the Department of Agriculture, Fisheries and Food is gratefully acknowledged.

\section{References}

Dillon, P. and Stakelum, G. 1989. Irish Journal of Agricultural Food and Research 28, 104 (Abstract).

Kyoto protocol, 1997. United Nations, Framework Convention on Climate Change

http://unfccc.int/resource/docs/convkp/kpeng.pdf Accessed 27th October 2009.

McGettigan, M., Duffy, P., Hyde, B., and O'Brien, P. 2008. Ireland - National Inventory report 2008, greenhouse gas emissions 1990-2006, EPA. http://erc.epa.ie/ghg/nirs/NIR_2009_IEv1.2.pdf Accessed 27th October 2009. 